\title{
11 Orchids for Pot Culture/ Hanging Baskets/ Tree Mounting
}

Orchids are one of the most distinctive plants of nature and highly priced in the international flower trade due to their incredible range of diversity in size, colour, shape, forms, appearance and long lasting qualities of flowers. They are considered to be highly valued cut flowers as well as potted plants. Out of 1331 species of orchids of India, 856 species are found in North Eastern Hill Region due to the congenial climatic conditions, diversified topography and altitudinal variation. Among flower crops, orchids contribute a 10\% share in international trade. In addition, the Sikkim Himalayan region is the centre of origin of an important species like Cymbidium. Other valuable genera of commercial importance available in the region are Coelogyne, Dendrobium, Paphiopedilum, Pleione, Rhyncostylis and Vanda etc. The varied agroclimatic conditions of our country are highly favourable for cultivation of commercial orchids like Cattleyas, Vanda, Dendrobium, Arachnis and Aerides in tropical areas, Cymbidium hybrids, Paphiopedilum, Dendrobium hybrids and Phalaenopsis in subtropical areas and Cypripediums, Cymbidiums etc in temperate areas. Among orchids, Cymbidium, Dendrobiums, Phalaenopsis, Cattleyas, Vandas, Arandas, Arachnis etc are used as cut flowers whereas Aerides, Arachnanthe, Bulbophyllum, Calanthe, Coelogyne, Eria, Phaius, Phalaenopsis, Pleione, and Rhyncostylis are used as potted orchids.

\subsection{Agronomic Management}

\subsubsection{Humidity}

The single dominant factor which affects the cultivation of orchids is humidity, which should be as high as $75-85 \%$. It varies species to species depending upon habit of growth, light, temperature and ecotypes. Monopodial orchids require higher humidity than sympodial ones. As rule of thumb, in high temperature, humidity should be kept high. The provision of misting units or foggers or even humidifiers will ensure adequate humidity, and standing water may be kept beneath the benches to improve humidity. Humidity ranges of some orchid genera are given below:

Dendrobium: 50-70\% Paphiopedilum, Cupripedium: 40-70\%

Cattleya, Laelia: 40-55\% Rhyncostylis, Aerides, Phalaenopsis, Vanda: 70-75\%

\subsubsection{Light}

Most orchids generally prefer indirect or filtered light. Although it varies species to species, growth habit and habitat, as the rule of the thumb, $50 \%$ shading is always

(cc)BY-NC-ND (C) 2014 Lakshman Chandra De, Promila Pathak, A.N. Rao, P.K. Rajeevan

This work is licensed under the Creative Commons Attribution-NonCommercial-NoDerivs 3.0 License. 
advised for most of the commercial orchids. Under enough light, orchid plants have short, plump stems with bright green leathery leaves. Yellowing, stunting and scorching of plants occur under too much light, while under too much shade plants have darker green, soft and succulent leaves with thin and spiny stems. Low light orchids are classified as those requiring 1200-2000 foot candles of light intensity, and originated from dense forests e.g. Phalaenopsis, Calanthe etc. Medium light orchids grow at the top of the tree canopies and prefer 2000-3000 foot candles of light intensity. Cattleya and related genera and hybrids fall into this category.

High light orchids grow in full sun habitats and need 3000 foot candles or more light intensity, which includes Cymbidium and vandaceous plants. Terete vandas like Vanda teres, $V$. hookeriana require plenty of sun light and can grow under direct sun whereas strap leaved vanda such as Vanda coerulea, V. tricolour, V. sanderiana can not tolerate direct sun and need 50-60\% shade during summer.

\subsubsection{Temperature}

Orchids are classified into three categories based on temperature. Warm orchids like Aerides, Vanda, Rhyncostylis and some Dendrobium species grow at day temperature up to $32.2^{\circ} \mathrm{C}$ and $15.5^{\circ} \mathrm{C}$ for a minimum night temperature; intermediate species like Cattleya, Laelia, Brassovola, Oncidium, Miltonia etc prefer $26.6^{\circ} \mathrm{C}$ days and $12.8^{\circ} \mathrm{C}$ nights. Cool species such as Cymbidium, Odontoglossum, Cypripedium etc. prefer $24^{\circ} \mathrm{C}$ days and $10^{\circ} \mathrm{C}$ nights. Most orchids require a lower night temperature for both robust growth and to initiate blooms. A night temperature of $10-13^{\circ} \mathrm{C}$ is ideal for initiation of flowering in Cymbidium. In Phalaenopsis, day and night temperatures of $24^{\circ} \mathrm{C}$ and $17^{\circ} \mathrm{C}$, respectively are essential for optimal flower production. Day temperatures above $21^{\circ} \mathrm{C}$ and night temperatures in the range of 15.5 to $21^{\circ} \mathrm{C}$ are favourable for Vanda. Small and young orchids require $5^{\circ} \mathrm{C}$ more temperature than mature plants.

\subsubsection{Atmosphere}

Fresh air and good circulation are essential for orchid production, full of continual light breezes, make a good source carbon dioxide for photosynthesis.

\subsubsection{Propagation}

Orchids are highly valued for long lasting cut flowers. Both monopodial (Single stemmed growth) and sympodial (Multistemmed growth) are preferred for commercial cultivation. Orchid genera like Aerides, Arachnis, Epidendrum, Renanthera, Phalaenopsis, Vanda and Dendrobium are propagated by cutting. Flower stalk cuttings are useful 
in genera like Phalaenopsis, Phaius, Calanthe and Thunia. Air layering is effective in Vanda. Genera of sympodial orchids like Cattleya, Dendrobium, Cymbidium, Epidendrum are multiplied by division. Off -shoots or keikis emerge from main stem are used as propagules in Dendrobium, Ascocenda and Phalaenopsis. The older canes of sympodial orchids like Cymbidium (called 'backbulbs') are forced to root in a moist medium. Seed culture involves germinating seeds and growing seedlings under aseptic condition in an agar medium supplemented with nutrients in Knudson C media. Various plant parts like shoot tips or meristem, leaf and leaf segments, stem segments, floral parts, aerial parts have been used for tissue culture of orchids. Among these, meristem and shoot tip culture are most popular for mass propagation of commercial species and hybrids, while axillary buds are good sources of explants in monopodials. Both liquid and solid media are used for culture of orchid tissues, with Knudson's C medium, Vacin and Went's medium, Murashige and Skoog's medium being the most widely used. Additives like coconut water (15\%) and banana pulp (10\%) are beneficial for the promotion of shoots, and mineral salts, carbon source, vitamins, plant growth regulators are used in the media. Sucrose is used as a carbon source to promote organogenesis at suboptimal concentrations and protocorm formation at supra-optimal concentrations.

Among vitamins, thiamine and growth regulators, auxin, cytokinins are used for callus formation. In vitro plants are hardened off in vitro only, before transferring to a main field. The application of paclobutazol delays chlorophyll loss, reduces the activities of enzymes and delays senescence. Nitsch media with carbon sources of $40 \mathrm{~g} / \mathrm{l}$ is suitable for the conservation of the Cymbidium hybrid 'Sleeping nymph'. It was also found that MS media with activated charcoal and sucrose at $20 \& 30 \mathrm{~g} / \mathrm{l}$ is suitable for fast multiplication of pseudobulbs.

The combination effect of BAP and NAA was found to be suitable for faster multiplication of pseudobulbs in Cymbidium hybrid 'Pine Clash Moon Venus' (MS +AC 1.5 $\mathrm{g} / 1+\mathrm{BAP} 0.05 \mathrm{mg} / 1+\mathrm{NAA}(0.25 \mathrm{mg} / \mathrm{l})$.

\subsubsection{Pots and Potting Media}

Terrestrial and semi-terrestrial plants like Paphiopedilum and Cymbidium perform better in deep pots. Orchid plants as a rule grow to be near one another to aid in creating a microclimate with higher humidity. Basket culture is useful for those orchids like Vanda, Rhyncostylis, Arachnis with pendent flower spikes and long dangling roots. Clay pots are best suitable for terrestrial orchids while plastic pots are used for epiphytes. Slabs or logs of tree fern are effective for cool growing orchids.

A potting media of terrestrial orchids should have equal parts of leaf mould, soil and sand. Clay soil, bonemeal, sawdust, charcoal dust, manure, wood savings etc. are also used in various proportions for satisfactory growth of terrestrial orchids.

A potting media consisting of charcoal, brick pieces and coconut fibre in equal proportions is ideal for vegetative growth and flowering of epiphytic orchids like Aerides, 
Dendrobium etc. Under low humid conditions (30\%), plastic pots with a mixture of bark/ perlite/sphagnum moss or osmunda are used. Under average humidity (35-50\%), it is advisable to use plastic pots with a mixture of bark and sphagnum moss. Under high humidity ( $55 \%$ and above), clay pots are used with bark, stone culture, charcoal or tree fern.

\subsubsection{Watering}

Most orchids are damaged by overwatering rather than under watering; overwatering leads to root rot and many other diseases. Most orchids prefer water of $\mathrm{pH}$ 5.0-6.5. Watering at lower or higher $\mathrm{pH}$ or with high levels of dissolved minerals can hamper nutrient uptake. Frequent watering is essential under high sunlight and high temperature conditions; plants in small containers dry out more quickly than in large containers. Plants in earthen pots require more watering than plants in plastic pots, while a hanging plant needs even more frequent watering as it has better aeration than onein a pot. More frequent watering is necessary for fresh potting materials and watering should be practiced either in the morning or in afternoon time. Potting materials having more moisture retention capacity (like coconut husk, tree fern etc) need less water less frequently, and vice versa.

\subsubsection{Nutrition}

Orchids are light feeders and require nitrogen from the first two-thirds of their life cycle. During rest period they do not need any fertilizers, but during flower initiation and inflorescence development, plants are fed with less nitrogen, more phosphorus and potassium. During blooming, a small level of nitrogen and phosphorus and high levels of potassium are maintained. In orchids, foliar feeding is found to be ideal. Frequent application of fertilizers at low concentrations is the best way of feeding orchids: a concentration of 0.2 to $0.3 \%$ of $30: 10: 10(\mathrm{~N}: \mathrm{P}: \mathrm{K})$ at the vegetative stage and 10:20:20 $(\mathrm{N}: \mathrm{P}: \mathrm{K})$ at blooming stage are applied for quality flower production. Sometimes, fresh coconut water and diluted cow urine are also useful as foliar sprays. In Cymbidium, foliar application of 0.3\% 19:19:19 of N, P, K at 7 days interval increased the plant height and leaf length. In Aerides multiflorum and Dendrobium moschatum, treatment with 1000 ppm $\mathrm{N}$ and 500 ppm each of $\mathrm{P}$ and $\mathrm{K}$ enhances vegetative growth and flowering. In the Dendrobium hybrid, 'Sonia 17' application of 0.2\% NPK (30:10:10) along with 200 ppm BA increases number of spikes per plant and number of flowers per spike.

\subsubsection{Repotting}

Orchid plants require repotting if there is no space left in the pots for new growths and if the substrate has decomposed or roots are rotting. Timing is the most important part 
of good repotting. The best time for repotting of an orchid is when new growth and new roots are just beginning to form (before those new roots reach even $1 \mathrm{~cm}$ long). In most orchids, this occurs right after flowering, indicating that repotting should be done between February and June.

\subsection{World Production Scenario of Potted Orchids}

The production of potted orchids for the mass market has gone beyond the United States and has global economic importance. The largest exporters of potted orchids include Taiwan, Thailand, the United Kingdom, Italy, Japan, New Zealand and Brazil, while the largest importer of potted orchids was the United States during 2002. The production of finished potted orchids in Europe is often for domestic consumption. In 2002, the total number of potted orchids produced in China and Japan were 4 million and 28 million, respectively. At flower auctions in Holland, Phalaenopsis orchids were the most valuable potted plant sold with a wholesale value of $€ 173.7$ in 2006. Potted Dendrobium orchids are produced in China, Taiwan, Thailand, Philippines, USA, Japan and Germany, while potted Vanda, Mokara, Oncidium, Cattleya, Ascocenda, Oncidium, Renanthera and Arachnis are produced in large scale in Thailand.

\subsection{Description and Culture}

Description and culture of orchids for pot culture, hanging baskets and tree mounting such as Aerides, Anoectochilus, Ascocentrum, Bulbophyllum, Coelogyne, Doritis, Epidendrum, Gastrochilus, Laelia, Miltonia, Odontoglossum, Renanthera, Rhyncostylis and Zygopetalum are given below (De, 2011; De, 2014).

\subsubsection{Aerides}

Aerides consists of more than 60 species. These are monopodial epiphytic orchids grown on trunks or branches of trees. The stems are round, leafy and branched with aerial roots. The strap leaves are thick, leathery and bilobed. The inflorescence is auxillary and drooping and up to $60 \mathrm{~cm}$ long in some species. The flowers are many and $2 \mathrm{~cm}$ in diameter, closely set on the inflorescence, and generally fragrant.

\subsubsection{Genetic Resources}

Aerides falcatum: It is distributed in the NEH Region, Thailand and Burma. The plants are $150 \mathrm{~cm}$ tall with narrow and thick leaves and pendulus or arching, $50 \mathrm{~cm}$ long inflorescence. The flowers are available in the month of March to May, white, tinted rose and fragrant. 
Aerides Lawrenceae: This species is distributed in Philippines. The plant is $150 \mathrm{~cm}$ tall with thin leaves and pendent inflorescence. Flowers are large, white, purple spotted and available in the autumn season.

Aerides multiflorum: This species is distributed in India, Burma, Thailand, Vietnam and the Himalayas. The plants are short stemmed with leathery leaves and densely flowered inflorescence. Flowers are fragrant, waxy, white with rose purple shades and available in June-July.

Aerides odoratum: This species is distributed in India, China, Himalayas, Burma, Thailand, Philippines and Indonesia. The plants are $150 \mathrm{~cm}$ tall with branched stems and leathery, bilobed leaves. The inflorescence is cylindrical, many flowered, pendulous, waxy white with touch of amethyl purple and fragrant. It is available in June-July.

Aerides album: A native of Philippines, $150 \mathrm{~cm}$ tall, branched and glossy green bilobed leaves. The inflorescence is pendent, arching and densely many flowered. The flowers are long-lasting, white with purple tipped petals and sepals and available in August-October.

\subsubsection{Intergeneric Hybrids}

Aredocentrum $=$ Aerides $x$ Ascocentrum

Aredefinetia $=$ Aerides $x$ Neofinetia

Aeridopsis $=$ Aerides $x$ Phalaenopsis

Aeridovanda $=$ Aerides $x$ Vanda

Renades $=$ Aerides $x$ Renanthera

Rhynchorides $=$ Aerides $x$ Rhyncostylis

\subsubsection{Common Commercial Hybrids}

'Edward', 'Brighton's Sparkle', 'Brighton Pink', 'Cagayan', 'Hollyhock', May Woo', 'Jueile', 'Pink Flush', 'Sandorata', 'Lokelani', ‘Cressida'.

\subsubsection{Uses}

Aerides is ideal for pots and slat baskets. They make spectacular specimen plants in baskets or mounted on trees with long flower stems. Scented species are utilized for the extraction of essential oils, and Aerides guttalum is used as an emollient drug. Tubers of Aerides crispum are rich in aeridin and phenanthropyran and anti-bacterial.

\subsubsection{Cultivation}

Aerides prefers a bright light of 2400-3600 foot candles, not direct sun. These plants perform well under warm humid conditions with plenty of free moving air, and should not be subjected to temperatures below $15^{\circ} \mathrm{C}$. A porous potting media consisting of shredded tree fern fibres or coarse bark along with gravels is ideal. These orchids 
grow throughout the year and require a good amount of water at all times. Fortnightly or monthly feeding with $1 / 2$ or $1 / 4$ strength of balanced fertilizers of $\mathrm{N}: \mathrm{P}: \mathrm{K}(20: 20: 20)$ is desirable. Aerides are easily propagated by keikis divisions.

\subsubsection{Anoectochilus}

Anoectochilus consists of about 25 species, which are commonly known as 'Jewel Orchids'. These are pseudobulbless terrestrial orchids with creeping rhizomes and petioled green, brown, copper colour veined and striated, rose, yellow or white leaves. Flowers appear in glandular pubescent spikes.

\subsubsection{Genetic Resources}

Anoectochilus albolineatus: This species is found in Burma and Malaya Peninsula and produce velvety dark purplish leaf with red veins.

Anoectochilus brevilabris: It is distributed in Sikkim, Arunachal Pradesh, Nepal and Bhutan. The plants are $10-30 \mathrm{~cm}$ tall having beautiful leaves patterned with pale gold to copper veins on velvety maroon brown leaves.

Anoectochilus roxburghii: A native to the Himalayas. The leaf is deep velvety green with lighter centre, veined and reticulated golden yellow, reddish margins.

Anoectochilus argyroneurus: This species is native to Java. Leaves are brilliant green, silvery white veined and green spotted.

Anoectochilus regalis: This species is from Sri Lanka. The leaves are dull green and bronze shaded veined and reticulated golden yellow.

Anoectochilus yunngianus: Leaves are brown green and covered with a network of gold and copper veins.

\subsubsection{Uses}

- Jewel orchids are grown for attractive foliages.

- Medicinal Anoectochilus:

- Anoectochilus formosanus: An anti-inflammatory agent, anti-febrigoagent, anti-depressing agent and against the virus influenza A.

- Anoectochilus roxburghii: Distributed in the Himalayas and Vietnam. It is rich in novel flavonoid glucoside and has potential in fighting cancer. Popular varieties are 'TE', 'Alba', 'Variegated', 'Variegated Alba'.

\subsubsection{Cultivation}

Plants grow well in intermediate to warm conditions under shade environment. They can be placed in a wet interior with one to two hours sunlight everyday. A well drained 
potting mixture consisting of sand, bark, perlite and soil is ideal. Plants are propagated by seeds or rhizomes.

\subsubsection{Arachnis}

Arachnis consists of more than 20 species and is commonly known as 'Scorpion Orchid.' These are monopodial epiphytic plants, $30 \mathrm{~cm}$ to $4.5 \mathrm{~m}$ tall with many leathery leaves. Leaves are strap shaped, clasping the stem at their base. Flowers are showy, large borne on simple racemes or branched panicles and the inflorescence is 50 to $65 \mathrm{~cm}$ long arise from the stem just above the clasping leaves. Flowers are green, yellow, brown and purple in colour.

\subsubsection{Genetic Resources}

Arachnis cathcartii: This species is distributed in Sikkim and Bhutan. Plants are 30-45 cm tall with bilobed coriaceous, lorate and leathery leaves. The inflorescence is stout, pendulous or horizontal. The flowers are fleshy, waxy, long lasting and pale yellow with red brown bands, and are available in March-April.

Arachnis clarkei: Distributed in Sikkim and Bhutan. Plants are 30-45 cm long. The inflorescence is 2-3 flowered. The flowers are fleshy, highly scented, fragrant and yellow barred with pale cinnamon brown. Flowers are available in the spring summer season.

Arachnis flos-aeris: Distributed in Sumatra, Borneo, Malaya Peninsula and Java. A stout stemmed climbing plant, $5 \mathrm{~m}$ tall with leathery, bilobed lanceolate leaves and ascending or drooping simple or branched inflorescence. The flowers are fleshy, long lasting, and a pale yellow green colour with dark purple brown bars and spots. Flowers are available in the spring-summer season.

Arachnis Maingayi: This species is distributed in Singapore to Borneo. The stems are $10-15 \mathrm{~cm}$ tall with linear oblong leaves and 30-90 cm long inflorescence. The flowers are whitish or faintly pinkish with purple or pink blotches and produced during April to May. Arachnis hookeriana (White Scorpion Orchid): Native to Borneo, Malayasia and Singapore. A hardy and frequently flowering species used as a parent for the development of hybrids for cut flowers.

\subsubsection{Inter-generic Hybrids}

These genera have the capacity to cross inter-specifically and multi-generically to evolve outstanding hybrids. Arachnopsis $=$ Arachnis $\mathrm{x}$ Phalaenopsis

Arachnostylis $=$ Arachnis $\mathrm{x}$ Rhyncostylis Aranda $=$ Arachnis $x$ Vanda 
Aranthera $=$ Arachnis $x$ Renanthera

Sappanara $=$ Arachnis $x$ Phalaenopsis $x$ Renanthera

Trevorara $=$ Arachnis $x$ Phalaenopsis $x$ Vanda

Laycockara $=$ Arachnis $x$ Phalaenopsis $x$ Vandopsis

Holttumara $=$ Arachnis $x$ Renanthera $x$ Vanda

\subsubsection{Common Commercial Hybrids}

Arachnis 'Maggie Oei Red Ribbon', Arachnis 'Maggie Oei Yellow Ribbon', Arachnis 'Maroon Maggie', Arachnis ‘Merry Maggie', Aranthera 'Bartha Braga', Aranthera 'Ishbel'.

\subsubsection{Uses}

Arachnis is commonly used in wedding decorations, flower arrangements etc. They are grown with stakes or beds with rods. Spider type early varieties are used as cut flowers.

\subsubsection{Cultivation}

They grow well in a temperature range of $18-20^{\circ} \mathrm{C}$, light intensity of $2400-3600$ foot candles and relative humidity range of 65 to $80 \%$. A compost mixture consisting of tree fern, bark, charcoal, cowdung manure, bonemeal and sandy loam soil is good for their cultivation. The plants are grown in well drained raised beds and pots with compost and other components like leaf moulds, sphagnum moss and gritty white sand.

\subsubsection{Ascocentrum}

Ascocentrum consists of six species. These are dwarf monopodial epiphytes and characterized by large spur hangs from the tip. The plants are small, compact with small strap shaped leaves and short stalked erect and cylindrical covered with many closely spaced flowers. Flowers are long lasting and 1-2 cm in diameter.

\subsubsection{Genetic Resources}

Ascocentrum ampullaceum: Distributed in the Himalayas, Burma and China. Plants are up to $20-25 \mathrm{~cm}$ tall with many flowered short stalked inflorescence. The flowers are $2.5 \mathrm{~cm}$ in diameter and rose carmine in colour. Flowers are available during March to May.

Ascocentrum curvifolium: Distributed in the Himalayas and Java. Plants are stout, $12.5 \mathrm{~cm}$ tall with rigid and fleshy leaves and densely flowered inflorescence. The flowers are purple to orange scarlet in colour and produced in spring summer. 
Ascocentrum miniatum: Distributed in Malayasia and the Himalayas, Borneo and the Philippines. Plants are dwarf (less than $15 \mathrm{~cm}$ tall) with linear, very fleshy leaves and cylindrical inflorescence crowded with densely flowers. Flowers are yellow to orange red and available in spring summer season.

Ascocentrum pumilum: An intermediate and cold loving dwarf species, $5 \mathrm{~cm}$ tall with needle like leaves and tiny pink flowers.

\subsubsection{Hybrids:}

It is cross compatible with Aerides, Neofinetia, Vanda and Rhyncostylis.

\subsection{Bigeneric Hybrids}

Aeridocentrum $=$ Ascocentrum $\times$ Aerides

Ascofinetia $=$ Ascocentrum $\times$ Neofinetia

Ascocenda $=$ Ascocentrum $\times$ Vanda

Renancentrum $=$ Ascocentrum $\times$ Renanthera

Asconopsis $=$ Ascocentrum $\times$ Phalaenopsis

\subsection{Trigeneric Hybrids}

Kagawara $=$ Ascocentrum $x$ Renanthera $\times$ Vanda

Eastonara $=$ Ascocentrum $x$ Gastrochilus $x$ Vanda

Christieara $=$ Aerides $x$ Ascocentrum $x$ Vanda

Komkrisara $=$ Ascocentrum $x$ Renanthera $x$ Rhyncostylis

Lowsonara $=$ Aerides $x$ Ascocentrum $x$ Rhyncostylis

Mokara $=$ Arachnis $x$ Ascocentrum $x$ Vanda

Nakamotoara $=$ Ascocentrum $\times$ Neofinetina $\times$ Vanda

Vascostylis = Ascocentrum $x$ Rhyncostylis $x$ Vanda

\subsection{Tetrageneric Hybrids}

Alphonsoara $=$ Arachnis $\times$ Ascocentrum $\times$ Vanda $\times$ Vandopsis

Bokchoonara $=$ Ascocentrum $\times$ Arachnis $x$ Phalaenopsis $x$ Vanda

Darwinara $=$ Ascocentrum $\times$ Neofinetia $\times$ Rhyncostylis $x$ Vanda

Dominyara $=$ Ascocentrum $\times$ Luisia $\times$ Neofinetia $\times$ Rhyncostylis

Knappara $=$ Ascocentrum $x$ Rhyncostylis $x$ Vanda $x$ Vandopsis

Moonara $=$ Ascocentrum $x$ Aerides $x$ Neofinetia $x$ Rhyncostylis

Okaara $=$ Ascocentrum $x$ Renanthera $x$ Rhyncostylis $x$ Vanda

Onoara $=$ Ascocentrum $x$ Renanthera $x$ Rhyncostylis $x$ Vanda

Pageara $=$ Ascocentrum $x$ Luisia $x$ Rhyncostylis $x$ Vanda

Robinara $=$ Ascocentrum $\times$ Aerides $\times$ Renanthera $\times$ Vanda 
Ronnyara $=$ Aerides $x$ Ascocentrum $x$ Rhyncostylis $x$ Vanda

Stamariaara $=$ Ascocentrum $\times$ Phalaenopsis $x$ Renanthera $\times$ Vanda

Yusofara $=$ Arachnis $x$ Ascocentrum $x$ Renanthera $x$ Vanda

\subsection{Pentageneric Hybrids}

Knudsonara $=$ Ascocentrum $\times$ Neofinatia $\times$ Renanthera $\times$ Rhyncostylis $\times$ Vanda

Paulara $=$ Ascocentrum $x$ Doritis $x$ Phalaenopsis $x$ Renanthera $x$ Vanda

Sutingara $=$ Arachnis $x$ Ascocentrum $x$ Phalaenopsis $x$ Vanda $x$ Vandopsis

\subsection{Common Commercial Hybrids}

'Sagarik Gold'.

\subsubsection{Uses}

Mature plants producing many keikis are excellent for specimen culture. Species are ideal for bamboo baskets or coir basket culture and produce brilliant orange flowers in the early spring. They can be mounted on slabs of bark. Hybrids are long lasting and used as cut flowers.

\subsubsection{Cultivation}

The plants are grown under protected conditions in a temperature range of 24 to $29^{\circ} \mathrm{C}$ during daytime and $6-8^{\circ} \mathrm{C}$ during the night, with a light intensity of $2400-3600$ foot candles and relative humidity of 70 to $90 \%$. They thrive in strong bright light and can be acclimated to direct sunlight. Exposures of the plants below $15^{\circ} \mathrm{C}$ can cause delaying of flowering. Ascocentrum orchids are best grown in pots in a porous media consisting of osmunda tree fern fibre, tree bark, brick pieces and charcoal. Hanging plants require regular watering or misting. These orchids are heavy feeders and best fertilized weekly with $1 / 2$ strength orchid fertilizers.

\subsubsection{Bulbophyllum}

Bulbophyllum consists of about 2500 species of orchids from tropical and subtropical Asia. The name indicates that the leaves are attached to the top of pseudobulbs. These orchids are sympodial epiphytes having rhizomatous stems with angled pseudobulbs. The pseudobulbs form a chain like growth on the rhizomes. Inflorescence is erect or pendent and arises from the base of the pseudobulb. The flowers are solitary or grow in an umbel or united on spurs. Flower size ranges from a few millimeters (Bulbophyllum minutissimum, B. minututum) to $40 \mathrm{~cm}$ in Bulbophyllum echinolobium. 


\subsubsection{Genetic Resources}

Bulbophyllum barbigerum: Native to tropical West Africa. The pseudobulb is small, flat terminating in a single leaf. The 8 to 14 flowers are borne on inflorescence, brown in colour, and are available in July-August.

Bulbophyllum careyanum: Pseudobulbs are egg shaped and 4-angled. Leaves are thick, leathery and tongue shaped. Inflorescence is many flowered and densely arranged. Flowers are $1 \mathrm{~cm}$ in diameter, sour smelling, white-yellow and spotted with brown red and produced during October-December.

Bulbophyllum cornu-cervi: This species is native to Sikkim. Pseudobulbs are globular, minute and crowded. Flowers are small and borne on slender and erect 8-10 cm long inflorescence. Flowers are greenish and produced in July.

Bulbophyllum cylindraceum: Distributed in Sikkim and Meghalaya. The rhizome is stout with obtuse leaves. The inflorescence is erect, cylindric and catkin-like nodding raceme. Flowers are black purple and available during October-January.

Bulbophyllum eublephrum: Native to Sikkim Himalaya. The pseudobulbs are cylindric. The inflorescence is raceme and lax flowered. Flowers are green and produced in August. Bulbophyllum falcatum: Native to tropical West Africa. The pseudobulbs produce one pair of leaves. Inflorescence is arranged with yellowish brown flowers marked with purple and produced in summer.

Bulbophyllum grandiflorum: Native to New Guinea. The single greenish brown flower is borne on a peduncle of $15-20 \mathrm{~cm}$ long and produced during July-August.

Bulbophyllum leopardinum: Distributed in Meghalaya. The rhizome is very short with pear shaped compressed bulbs. The inflorescence is short and 1 to 3 flowered. The flowers are fragrant, whitish, spotted with crimson and produced during OctoberNovember.

Bulbophyllum lobbii: Native to Burma and Malay Peninsula. The rhizome is stout with egg shaped pseudobulbs and leathery leaves. Flowers are solitary, fragrant, waxy and long lasting.

Bulbophyllum macranthum: Native to Java, Borneo, Sumatra and Malayasia. The flowers are whitish, densely spotted with purple and produced in spring season.

Bulbophyllum makoyanum: Native to Singapore. Pseudobulbs are ovoid with tongue shaped leaves. The flowers are scented, reddish with darker spots and fringed with yellow hairs.

Bulbophyllum medusae: Native to Malayasia. The plant is a creeper and arranged with 20 $\mathrm{cm}$ long flower stalk having a dense head of fragrant flowers. The flowers are white, cream white or pink or red spotted.

Bulbophyllum rigidum: Distributed in Sikkim Himalaya. The rhizomes are pseudobulbous and $25 \mathrm{~cm}$ long and $5 \mathrm{~cm}$ broad leaves arose from it. The inflorescence is sparsely flowered. The flowers are yellowish tinged with green and streaked with red and produced in MayJune.

Bulbophyllum striatum: Distributed in Meghalaya. The pseudobulbs are ovoid. The inflorescence is 2 to 4 flowered. The flowers are yellow-green stripped with purple and produced in October. 
Bulbophyllum thomsonii: Distributed in Coorg, Mysore, Nilgiris and the Annamalai Hills. The rhizome is slender with sub-globose pseudobulbs and round, ovate-lanceolate leaves. The inflorescence is erect, lax flowered and 6-10 flowered. The flowers are yellow tipped with purple.

Bulbophyllum appendiculatum: Distributed in North East states of India. Pseudobulbs are ellipsoid cylindric with fleshy, erect, sessile leaves. Inflorescence is one flowered and erect. Flowers are deep purple and produced in October-November.

Bulbophyllum bisetum: A dwarf species, distributed in all North East states of India. Pseudobulbs are small, oval shaped and unifoliate. Inflorescence is pendent racemose and 10-15 flowered. The flowers are dull purple with green yellow margins and produced in July-September.

Bulbophyllum cariniflorum: A dwarf species from Arunachal Pradesh and Sikkim. Pseudobulbs are ovoid to cylindric and ridged. Inflorescence is racemose and many flowered. Flowers are scented, greenish yellow with a bright yellow tip and produced in July-August.

Bulbophyllum crassipes: A robust species distributed in all states of North East India. Pseudobulbs are conical and many flowered with coriaceous oblong leaves. Flowers are yellow with purple spots and produced in September-October.

Bulbophyllum cauliflorum: Distributed in all North East states of India. Pseudobulbs are cylindric with linear-oblong leaves. Inflorescence is umbellate and 3-5 flowered. Flowers are pale yellow green with a yellow lip.

Bulbophyllum helenae: A native to all North East states of India. Pseudobulbs are ovoid with linear oblong leaves. Inflorescence is umbellate and 6-9 flowered. Flowers are orange red in colour and produced in May-July.

Bulbophyllum hirtum: Distributed in Arunachal Praadesh, Meghalaya, Nagaland and Sikkim. Pseudobulbs are crowded, ovoid cylindric with oblong-lanceolate leaves. Inflorescence is erect, racemose and many flowered. Flowers are scented, pale greenish white and produced in October-January.

\subsubsection{Hybrids}

\subsection{Common Commercial Hybrids}

'Ray Gabaldon', 'A dorbil Ring', 'Madeline Nelson', 'Tsiku Goldfinder', 'Fredensborg Delight', 'Swissthai Alamia', 'Jan Ragan', 'Wilmer Shear Magic', 'Jim Clarkson', 'Tsiku Taurus', 'Agathe', 'Short and Sweet', 'B.C.', 'Chua', 'Aquarius', 'Chanthaboon Glory', 'Meen Bulbul', 'Meen Candy Baby', 'Supat Sun Radiant', 'Supernova’, 'Tee Dragon Fly’, ‘Tee Naga’, 'Puch Golden Hydra’, 'Tee Gigantic Condor’, ‘Grace Thoms’.

\subsubsection{Medicinal Bulbophyllums}

Bulbophyllum odoratissimum: This species is distributed in China, Nepal, Sikkim, Bhutan and Thailand. Plants are rich in phenanthrene, lignan, flavonoids, biben- 
zyls, phenolic glycosides, aldehydes and acids. Plants are used to treat tuberculosis, chronic inflammations and fractures.

Bulbophyllum inconspicuum: In Japan, it is used as an expectorant and in the treatment of stomach cancers.

Bulbophyllum albidum: In Western Ghats, leaves and bulbs are used to strengthen a weak uterus for conception.

Bulbophyllum kwangtungense: In China and Japan, tubers are used for the treatment of pulmonary tuberculosis and fever. This species is rich in dihydrodibenzoxepins, densifloral A, cumulatin and plicatol B.

\subsubsection{Uses}

Cluster pseudobulb-bearing species grow well in shallow pans whereas long rhizome bearing species do better in baskets or slabs.

\subsubsection{Cultivation}

All tropical bulbophyllums grow in a flat pot, hanging or suspended on cork bark in a humid semi-shaded location where the temperature range is 15 to $27^{\circ} \mathrm{C}$. These orchids like slightly drier conditions in between waterings and require a rest in winter when they are not growing. They also require good light but it is best if they are shaded from bright, direct summer sun. In summer, humidity level should be maintained at $70 \%$ and $50-60 \%$ in winter. Plants are easily propagated through division of clumps while repotting. A potting mixture of cocochips, bark pieces and brick pieces is ideal. During active vegetative growth, a half dose of balanced 20:20:20 fertilizer is applied twice a month.

\subsubsection{Coelogyne}

Coelogyne consists of 200 species of sympodial and pseudobulbous orchids. The pseudobulbs are topped by 2 to 4 leaves, slender in size and arranged along with creeping rhizomes. The leaves are coriaceous, thick and leathery with pronounced stalks. Inflorescences are erect or pendulous. The flowers are white or shades of brown, yellow and green and subtended by a papery bracts.

\subsubsection{Genetic Resources}

Coelogyne asparata: Distributed in Malay Peninsula, Borneo, Sumatra and New Guinea. Pseudobulbs are vigorous, ovoid, clustered and carrying each pair of huge leaves up to $60 \mathrm{~cm}$ long and $12.5 \mathrm{~cm}$ wide. Inflorescences are arching or pendulous and bear 12 to 18 flowers. The flowers are fragrant, heavily textured, creamy white with reddish brown lip and produced during spring-summer. 
Coelogyne barbarata: Distributed in Nepal, Bhutan and India. The pseudobulbs are pale green in colour, clustered, ovoid with stalked leathery leaves. The inflorescence is densely flowered, erect or arching. The flowers are white, spotted deep brown and produced in autumn and winter.

Coelogyne cristata: Native to higher elevations of Himalayan region. The pseudobulbs are spherical or egg shaped and clustered with soft textured linear-lanceolate leaves. The inflorescences are semi-erect, many flowered. The flowers are large, pure white with yellow ridges on lip and are produced during January to May.

Coelogyne quadrangularis: Distributed in Thailand, Malaya Peninsula, Sumatra, Java and Borneo. The pseudobulbs are conical, strongly ribbed with short stalked leathery leaves. The flowers are fragrant, $5 \mathrm{~cm}$ in diameter, long lasting, dull yellow brown lined with whitish lips and produced in spring summer.

Coelogyne elata: Native to higher elevations of the Himalayan regions. The pseudobulbs are cylindrical to ovoid with stalked heavily textured leaves. Inflorescence is erect, $60 \mathrm{~cm}$ tall and arranged with 7 to 10 flowers. The flowers are fragrant, long lasting, milky white with an orange tip.

Coelogyne flaccida: Naturally distributed at higher elevations of Sikkim and Meghalaya. The pseudobulbs are oblong, bifoliate. The inflorescence is pendulous and loosely arranged with 5 to 12 medium sized creamy flowers. The flowers are highly scented and produced during March to May.

Coelogyne graminifolia: Native to India, Burma, Thailand and Malay Peninsula. The pseudobulbs are borne on creeping rhizomes with pairs of leaves. The inflorescence is $15 \mathrm{~cm}$ tall, arching and 2 to 4 flowered. The flowers are $5 \mathrm{~cm}$ across, scented, white and produced during January to April.

Coelogyne Huettneriana: Native to Burma and Thailand. The pseudobulbs are irregular dark green and bifoliated. The inflorescence is arching and arranged with 12 flowers. The flowers are fragrant, white, long lasting, $5 \mathrm{~cm}$ across with citron yellow lip and produced during summer and spring.

Coelogyne lawrenceana: Native to Vietnam. The pseudobulbs are bifoliate, ovoid, clustered and heavily ribbed. The inflorescence is terminal, arching and bearing 1 to 3 flowers. The flowers are $5 \mathrm{~cm}$ in diameter, pale yellow with orange lip and produced in July.

Coelogyne massangeana: Distributed in Sumatra, Java, Malaya, Thailand and Borneo. The pseudobulbs are ovoid, bifoliate, yellow green with elliptic leaves. The inflorescence is pendulous and 15 to 20 flowered. The flowers are fragrant, $6 \mathrm{~cm}$ in diameter, pale yellow with brown side lobed lip and produced in spring and summer.

Coelogyne odoratissima: Distributed in India and Sri Lanka. This species is bifoliate with sheathed pseudobulbs and linear leaves. The inflorescence is loosely arranged with 2 to 5 flowers. The flowers are fragrant, white with yellow stripes and produced in spring and summer.

Coelogyne pandurata: Native to Malay Peninsula, Sumatra and Borneo. The pseudobulbs are compressed on both sides, smooth and leathery leaves. The inflorescence is arching, 20 flowered. The flowers are highly fragrant, emerald green in colour with white mottled lip and produced in autumn. 
Coelogyne speciosa: Native to Sumatra, Java and the Lesser Sunda Islands. The pseudobulbs are ovoid, clustered and bifoliate with arrow elliptic leaves. The inflorescence is 2 to 3 flowered, slender and abbreviated. The flowers are long lasting, musk scented, $7.5 \mathrm{~cm}$ across, yellow brown with yellow tip and produced during summer and spring.

Coelogyne ocultata: A subtropical to temperate species of Arunachal Pradesh, Meghalaya, Nagaland and Sikkim. Pseudobulbs are green, tapering at both ends and bifoliate. The inflorescence bears 2-3 flowers. Flowers are 2.5 to $4.5 \mathrm{~cm}$ across and white with blotched yellow tips. Flowers are produced in June-July.

Coelogyne ovalis: A subtropical species from Arunachal Pradesh, Assam, Meghalaya, Nagaland and Sikkim. Pseudobulbs are oval to spindle shaped. The inflorescence bears 2-3 flowers of pale yellow green to pale brown with a brown marking lip. The flowers are produced in October-December.

Coelogyne corymbosa: A subtropical to temperate species from Bhutan, India and Nepal. Pseudobulbs are ovoid, clustered and bifoliate. Inflorescence is erect or pendent and 2-4 flowered. Flowers are fragrant and white or with four yellow markings bordered with orange red lip and produced in April-May.

Coelogyne fuscescens: A subtropical to temperate species from Bhutan, India and Nepal. Pseudobulbs are bifoliate. The inflorescence bears 2 to 10 flowers. The flowers are $5 \mathrm{~cm}$ across, pale yellow to pinkish brown with orange red lip and produced during October-December.

Coelogyne prolifera: A subtropical species from Sikkim, Meghalaya and Nepal. Pseudobulbs are round. The inflorescence is slender-peduncle and 3-8 flowered. The flowers are yellow, 1-1.5 cm in diameter and produced during May-August.

Coelogyne fimbriata: Native to Sikkim and Meghalaya. Inflorescence is erect raceme and bears 8-10 yellow flowers. Flowers are produced in October-December.

Coelogyne flavida: Native to Sikkim, Manipur and Meghalaya. Flowers are yellow and produced during March -May.

Coelogyne ochracea: Native to Assam and Sikkim. Inflorescence is erect and bears 8-10 flowers. Flowers are small, white and fragrant and produced in May-June,

Coelogyne nitida: Native to Bhutan, Assam, Meghalaya and Sikkim. Flowers are white with two yellow red margin blotches on lip. Flowers are produced during March-May. Coelogyne rigida: Native to Nilgiri hills, Sikkim and Meghalaya. Inflorescence bears 5-7 flowers, pale yellow in colour and produced in June-July.

\subsubsection{Hybrids}

\subsection{Inter-specific Hybrids}

'Memoria W. Micholitz', 'Linda Buckley', 'Burfordiense', 'South Carolina', 'G. Beryl Read', 'John Leathers', 'Wood Fairy', 'Carolyn Sue', 'Golden Bug', 'Spring Showers', 'Professor Georges Morel', 'Joel Strandberg'. 


\subsection{Variety-species Hybrid}

'Memoria Fukuba', 'Memoria Okami', Memoria Tokiko'.

\subsubsection{Coelogyne for Hanging Baskets}

Coelogyne asperata, Coelogyne cristata, Coelogyne foestermani, Coelogyne longifolia, Coelogyne pandurata.

\subsubsection{Coelogyne for Herbal Medicines}

- Coelogyne cristata: Juice of pseudobulb is applied to boils.

- Coelogyne corymbosa: A paste of pseudobulb is applied to forehead to relieve headache.

- Coelogyne flaccida: A paste of pseudobulb is applied to forehead to treat headache. Juice is also consumed for indigestion.

\subsubsection{Cultivation}

There are high elevation and low elevation species and hence they are divided into two major groups, and environment requirements vary between groups. Cool growing species require a summer day temperature of $21-24^{\circ} \mathrm{C}$ and night temperature of $14-15^{\circ} \mathrm{C}$; winter day temperature of $11-13^{\circ} \mathrm{C}$ and night temperature of $2-5^{\circ} \mathrm{C}$, light intensity of 2000-3000 foot candles and relative humidity of 60-70\%. Strong air movement is essential. They are best grown in baskets containing a potting mixture of tree bark, charcoal and sphagnum moss. A balanced fertilizer mixed to $1 / 4$ to $1 / 2$ of the recommended strength should be applied weekly during periods of active growth. Many growers recommend using a fertilizer lower in nitrogen and higher in phosphorus during late summer and autumn to promote better blooming the next season and to allow the new growths to harden before winter. Over watering should be avoided.

\subsubsection{Doritis}

Doritis is a monotypic epiphytic orchid from Burma to Sumatra. Doritis pulcherrima is a small, stemless and clump forming monopodial with oblong elliptic leathery leaves. The inflorescence is erect and arranged with 25 flowers. The flowers are 1.5 to $4.0 \mathrm{~cm}$ in diameter with pear shaped lips. The flowers are dark lavender, rose purple, or magenta rose in colour and produced during the autumn and winter seasons.

\subsubsection{Primary Hybrids}

Primary hybrids evolved through crosses between Doritis pulcherrima and Phalaenopsis spp. are listed below: 
'Anna -Larati Soekardi', 'Annie Van Tweel’, 'Asahi', 'Bandung Pink', 'Bonita', 'Celebrant', 'Charm', 'Imp', 'Jim', 'Jim Chan', 'Kelsey Blush', 'Keneth Schubert', 'Musick Surprise', 'Myriam Esther', 'Profusion', 'Purple Gem', 'Purple Passion', 'Purple Sum', 'Red Elf', 'San Shia Appendo' Sandrine Dream', 'Si Kancil', Siam Treasure', 'Suka Hati', 'Summer Red', 'Sweet Gem', 'Tan Swee Eng.', 'Tarina'.

\subsubsection{Inter-generic Hybrids}

Doriella $=$ Doritis $x$ Kingiella

Doritaenopsis $=$ Doritis $x$ Phalaenopsis

Rhyndoropsis $=$ Doritis $x$ Phalaenopsis $x$ Rhyncostylis

Vandoritis $=$ Doritis $x$ Vanda

\subsubsection{Commercial Uses}

Ideal for pot plants or as cut flowers.

\subsubsection{Cultivation}

The plants require indirect sunlight and are shade loving plants that should be kept in a warm greenhouse with high humidity. For growing these plants, the optimum temperature range is 18 to $21^{\circ} \mathrm{C}$, relative humidity 60 to $70 \%$ and light intensity ranges from 1500-1800 foot candles. The most suitable potting media is chunks of hardwood charcoal or a mixture of bark, tree fern fibre and charcoal. The spraying of liquid fertilizers once every fortnight is beneficial.

\subsubsection{Epidendrum}

Epidendrum consists of more than 1000 species of epiphytic orchids of America. The pseudobulbs are very elongated or short with coriaceous leaves. Some leaves are thick whereas in some cases they are leathery with 2 to 4 leaves at the apex of each pseudobulb. In the case of reed like types, the leaves are alternate. The inflorescence is terminal, simple or profusely branched, erect or pendulous. The number of flowers varies from one to many per inflorescence. The size of flower ranges from $2 \mathrm{~cm}$ to $7.5 \mathrm{~cm}$ in diameter and highly scented. The flowers are varied in colour.

\subsubsection{Genetic Resources}

Epidendrum atropurpureum: Distributed in Mexico to Panama. The pseudobulbs are egg shaped, glossy, purplish, and $10 \mathrm{~cm}$ tall with rigid, leathery leaves. Inflorescence is $60 \mathrm{~cm}$ tall, racemose, erect or arching and 2 to 10 flowered. The flowers are chocolate brown, marginated with apple grren, scented and produced in spring-summer season. 
Epidendrum Brassovolae: Native to Central America. The pseudobulbs are clustered or borne on a stout rhizome and 25-30 cm long. The leaves are 2 to 3 leathery and yellowish green. Inflorescence is erect, long stalked, $45 \mathrm{~cm}$ long, 6 to 9 flowered. The flowers are fragrant, $10 \mathrm{~cm}$ across, deep yellowish brown to greenish and produced in March-April.

Epidendrum ciliare: Native to tropical America. The pseudobulbs are spindle shaped or cylindrical, $18 \mathrm{~cm}$ tall, borne on a creeping rhizome, terminated by two rigid elliptic oblong leaves. The inflorescence is racemose, $30 \mathrm{~cm}$ long with loosely arranged flowers. The flowers are $17 \mathrm{~cm}$ across, sweet scented, greenish white with trilobed white lip and produced during December-January.

Epidendrum cochleatum: Distributed in South Florida to Brazil. The pseudobulbs are $15 \mathrm{~cm}$ tall, pear shaped and clustered with paired light green leaves. The inflorescence is erect or arching, $60 \mathrm{~cm}$ tall, 8 to 12 flowered. The flowers are sweetly scented, greenish yellow with velvety red purple black lips.

Epidendrum fucatum: Native to Mexico, Guatemala and Cuba. The pseudobulbs are ovoid, $7.5 \mathrm{~cm}$ tall and clustered with 2 to 3 leathery, linear, $30 \mathrm{~cm}$ long leaves. The flowers are $4 \mathrm{~cm}$ across, long lasting, fragrant and yellowish or butter yellow in colour and produced in autumn-winter.

Epidendrum radicans: Native to Central and South America. The stems are elongated, $18 \mathrm{~cm}$ long, branched and offset forming rigid fleshy leaves. The inflorescence is erect or arching, terminal and $1.2 \mathrm{~m}$ tall. The flowers are $4 \mathrm{~cm}$ across, red, orange, scarlet, vermillion, orange red or yellow in colour and produced during summer.

Epidendrum vittellinum: Native to Mexico and Guatemala. The pseudobulbs are ovoid-conical, clustered with 2 to3 linear lanceolate to oblong, leathery leaves. Inflorescence is erect, branched, $45 \mathrm{~cm}$ tall and 10-12 flowered. The flowers are $4 \mathrm{~cm}$ in diameter, long lasting and vermillion with orange yellow lip.

Epidendrum xanthimum: A rare species. Flowers are bright yellow and orange and produced in masses.

Epidendrum parkinsonianum: It is pseudobulbless with pendent succulent leaves. Flowers are large, exotic, white and highly scented.

\subsubsection{Inter-generic Hybrids}

Brasso-epidendrum = Epidendrum $\times$ Brassovola

Vaughmara $=$ Epidendrum $\times$ Brassovola $\times$ Cattleya

Yamadara $=$ Epidendrum $\times$ Brassovola $\times$ Cattleya $\times$ Laelia

Epitonia = Epidendrum $\times$ Broughtonia

Epicattleya = Epidendrum $\times$ Cattleya

Arizara $=$ Epidendrum $\times$ Cattleya $\times$ Domingoa

Epilaeliocattleya $=$ Epidendrum $\times$ Cattleya $\times$ Laelia

Kirchara $=$ Epidendrum Cattleya $\times$ Laelia $\times$ Sophronitis

Epidiacrinum $=$ Epidendrum $\times$ Diacrinum 
Epilaelia = Epidendrum $x$ Laelia

Epiphronitis $=$ Epidendrum $\times$ Sophronitis

\subsubsection{Intervarietal Hybrids}

'Happy Valley’, 'Little Valley’, 'Lovely Valley’, ‘Spring Valley’, 'Lions Mane’, 'Lions Pride', 'Peace Valley', 'Lucky Valley', 'Pacific Classic', 'Pacific Mandarin', 'Pacific Parade', 'Pacific Secret', 'Pacific Volcano', 'Apricot Valley', 'Rain Valley', 'Water Valley', 'Pacific Joy’, 'Pacific Globe', 'Pacific Flame', 'Pacific Heat', 'Pacific Glory’, 'Walnut Valley’, Fireball', 'Autumn', 'Lunar Eclipse’, 'Pacific Dream', 'Pacific Lights', 'Pacific Shore', 'Pacific Delight', 'Pacific Mulberry', 'Pacific Storm', 'Candy Valley', 'Holy Valley', 'Palm Valley', ‘ Milky Valley’, Darling Jungle', 'Pacific Girl’, 'Pacific View'.

\subsubsection{Inter-specific Hybrids}

'Cire Blanche', 'Thomas Ott', 'Little Miss Sunshine', 'Saranac Lake’, 'Eddy Lick Run', 'Michael Riley', 'Ross Newman', 'Daves', 'Delectable Deliration', 'Orange Park', 'Cascade Blanche', 'Fuzzy Grapes', 'Doctor Ben', 'Suzuka Mars', 'Pink Lemonade', 'Golden Judy', 'Patricia Sander', 'Candy Dandy’.

\subsubsection{Variety-species Hybrids}

'Saint Nicholas', 'Wild Innovation', ‘Chocolate Cherry Supreme', 'Costa Lense', 'Spirit of Volunteerism', 'Songbirds', 'Topaz Cherry’, 'Topaz Prolific', 'Spirit of Giving’, 'Topaz Gem', ‘ Hula Dancer', 'Pacific Sunshine’, 'Topaz Butterball’.

\subsubsection{Epilaelia Hybrids}

'Royal Velvet', 'Topaz Sundaze', 'Irene', ‘Sedona', ‘Excaliber', ‘Topaz Seduction', 'La Motte', 'Heart of Darkness'.

\subsubsection{Epilaeliocattleya Hybrids}

'Chocolate Kisses', 'Kopaa', 'Rainbow Sherbet', 'Pixford', 'Tiny Magic', 'Highland Canary', 'Pseudogold', 'Jackie Bright'.

\subsubsection{Epicattleya Hybrids}

'Cathy Meincer', 'Painted Hill Star', ‘ Calandria', 'Erin Routon', 'Burdekin Honey’, 'Peles Flame'. 


\subsubsection{Medicinal Epidendrum}

A Brazilian species namely Epidendrum mosenii is used to treat infective and dolorous processes.

\subsubsection{Edible Epidendrum}

The leaves of Epidendrum ibaguense are edible, resembling the taste of watermelon, and can be chewed like bubblegum.

\subsubsection{Cultivation}

The optimum temperature range is 12 to $21^{\circ} \mathrm{C}$, relative humidity $50-60 \%$ and light 2400 to 3600 foot candles for successful growth and flowering. They grow in beds or pots with excellent drainage. Moderate shade during the summer and plenty of water during active growth are required. The pot mixture comprises of tree bark and charcoal mixture. Spraying with 0.3\% NPK (10:10:10) every two weeks is beneficial.

\subsubsection{Gastrochilus}

Gastrochilus consists of 20 species of epiphytic orchids distributed in India, East Asia and Malaysia. These are short to long stemmed epiphytic orchids with 6 to 11 lance shaped, thick, leathery leaves. The inflorescences are solitary or spicate with one or more flower spikes arising from the axil of the leaves. The flowers are attractive, 1 to $4 \mathrm{~cm}$ in diameter and white in colour with reddish spots and blotched with yellow.

\subsubsection{Genetic Resources}

Gastrochilus bellinus: Native to Burma and Thailand. The stems are stout with leathery, tongue shaped leaves. The inflorescence is 4 to 7 flowered, erect and robust. The flowers are long lasting, $4 \mathrm{~cm}$ in diameter and fragrant. The flowers are greenish yellow with purple spots and blotches and are produced during winter and spring. Gastrochilus calceolaris: Distributed in Meghalaya, Thailand, Sumatra, Java, Burma and Malayasia. The plants are short and stout stemed with tongue shaped leathery leaves. The inflorescence is stout, 3 to 6 flowered and purple spotted. The flowers are fragrant, waxy, $2 \mathrm{~cm}$ across, long lasting, greenish or yellowish with brown or purplish spots and produced during March-April.

Gastrochilus acutifolius: Native to Bhutan, India and Nepal. Stems are slender, pendent with oblanceolate leaves. Inflorescence is umbellate and many flowered. Flowers are fleshy, fragrant, spotted and flushed with brown and are produced during November-December. 
Gastrochilus obliquus: Native to Bhutan, West Bengal, Sikkim and Arunachal Pradesh. A dwarf species, 20-15 cm tall with stout pendent stems bearing 3-5 oblong fleshy leaves. The inflorescence is pendent, corymbose to umbellate and many flowered. The flowers are bright yellow, purple spotted and produced during NovemberDecember.

\subsubsection{Uses}

The rhizomes of Gastrochilus pandurata are used by natives of Java as a medicine and as a spice.

\subsubsection{Cultivation}

These orchids grow well in small pots or baskets. They prefer a warm, humid atmosphere and well lighted and ventilated places. The optimum temperature is 15 to $18^{\circ} \mathrm{C}$, light $1800-2400$ foot candles and relative humidity is 60 to $80 \%$ for proper growth and flowering of these plants. They grow well on tree fern fibre or chunks of hard wood charcoal. Spraying of complete fertilizer mixture is recommended at fortnightly intervals. The plants should be liberally watered during their active period of growth.

\subsubsection{Laelia}

Laelia consists of 75 species of epiphytic orchids from Cuba and Mexico to Argentina. These sympodial orchids possess pseudobulbs of various sizes and shapes, e.g., Laelia harpophylla have needlelike pseudobulbs. Another group bearing flat and round pseudobulbs is L. rubescens, while other groups have ovoid or egg shaped pseudobulbs, such as $L$ anceps. The number of leaves per pseudobulb ranges from 1 to 3 . The leaves are leathery, entire, thick and $5 \mathrm{~cm}$ to $30 \mathrm{~cm}$ in length. The inflorescence bears more than 20 flowers in some species, while others bear solitary flowers close to the pseudobulb apex. The flowers are lavender, white, yellow and orange in colour.

\subsubsection{Genetic Resources}

Laelia anceps: Native to Mexico and Honduras. The pseudobulbs are stout, ovoid-oblong, glossy, purple flushed, quadrangular, clustered and borne on stout rhizomes. The leaves are solitary, leathery and glossy green and oblong lanceolate. The inflorescence is elongated, slender, erect or gracefully arching with 1 to 6 flowers, $60 \mathrm{~cm}$ long. The flowers are lilac-pink, scented, $10 \mathrm{~cm}$ across and produced during December-January. 
Laelia autumnalis: Native to Mexico. The pseudobulbs are short, clustered, sub-conical and ribbed with 2 to 3 leathery, lanceolate leaves. Inflorescence is elongated, $90 \mathrm{~cm}$ long, loosely arranged, with 5 to 10 flowered raceme. The flowers are pinkish purple, waxy, long lasting, $10 \mathrm{~cm}$ across and produced in December-January.

Laelia cinnabarina: Native to Brazil. The pseudobulbs are elongated, $25 \mathrm{~cm}$ long and red purple with solitary, thick leathery rigid, $60 \mathrm{~cm}$ long purple leaves. The inflorescence is erect or arching and 5 to 20 flowered. The flowers are star shaped, orange red, long lasting, $7.5 \mathrm{~cm}$ across and are produced during March to May.

Laelia pumila: A dwarf species from Brazil. Pseudobulbs are terete and glossy dark green in colour. The leaves are fleshy, rigid, elliptic oblong and solitary. The inflorescence is $8 \mathrm{~cm}$ long and single flowered. The flowers are long lasting, fragrant, $10 \mathrm{~cm}$ across, pink purple in colour and produced in September to October.

Laelia purpurata: Indigenous to Brazil. The pseudobulbs are club shaped, robust, fusiform, compressed, glossy and yellowish green with leathery, solitary, dark green, thick leaves. The inflorescence is stout and 12 flowered. The flowers are fragrant, long lasting, $22.5 \mathrm{~cm}$ across, white, pale purple in colour and produced during May to July.

Laelia superbiens: A robust species from Mexico, Guatemala and Honduras. The pseudobulbs are elongated, fusiform, compressed and furrowed with one or two leathery, oblong to oblanceolate leaves. The inflorescence is $130 \mathrm{~cm}$ long, stout and 20-25 flowered, and borne in clusters in terminal raceme. The flowers are scented, long lasting, $12.5 \mathrm{~cm}$ across, rose coloured with purple yellow lips and are produced during January-February.

Laelia tibicinis: This is a robust species from Central America. The pseudobulbs are swollen -cylindrical, hollow, densely clustered, fusiform and yellow with 3 to 5 , rigid yellow green, oblong elliptic, heavy textured leaves. The inflorescence is erect or arching and $150 \mathrm{~cm}$ tall bearing handsome flowers at the tip. The flowers are variable in colour, sweet scented, long lasting, $8.5 \mathrm{~cm}$ across and produced during the spring season.

Laelia milleri: A lithophytic orchid originating from Brazil. A robust plant bears small orange-red flowers measuring $5 \mathrm{~cm}$ across.

Laelia liliputiana: Native to Brazil. A very small plant with $1 \mathrm{~cm}$ long pseudobulb, $2 \mathrm{~cm}$ long leaves and flowers that are $3 \mathrm{~cm}$ across.

\subsubsection{Bigeneric Hybrids}

Brassolaelia $=$ Laelia $\times$ Brassovola

Laelonia = Laelia $x$ Broughtonia

Laeliocattleya = Laelia $x$ Cattleya

Dialaelia $=$ Laelia $\times$ Diacrinum

Sophrolaelia $=$ Laelia $\times$ Sophronitis 


\subsubsection{Trigeneric Hybrids}

Laeliocattkeria = Laelia $\times$ Barkeria $\times$ Cattleya

Brassolaeliocattleya = Laelia $\times$ Brassovola $x$ Cattleya

Lawara = Laelia $\times$ Brassovola $\times$ Sophronitis

Hartara $=$ Laelia $\times$ Broughtonia $\times$ Sophronitis

Dialaeliocattleya = Laelia $\times$ Cattleya $\times$ Diacrinum

Epilaeliocattleya = Laelia $\times$ Cattleya $\times$ Epidendrum

Sophrolaeliocattleya = Laelia $x$ Cattleya $x$ Sophronitis

Dillonara $=$ Laelia $\times$ Epidendrum $\times$ Schomburgkia

\subsubsection{Tetrageneric Hybrids}

Iwanagara $=$ Laelia $\times$ Brassovola $\times$ Cattleya $\times$ Epidendrum

Yamadara $=$ Laelia $\times$ Brassovola $\times$ Cattleya $\times$ Epidendrum

Rechara $=$ Laelia $\times$ Brassovola $\times$ Cattleya $\times$ Schombergkia

Potinara $=$ Laelia $\times$ Brassovola $\times$ Cattleya $\times$ Sophronitis

Kirchara $=$ Laelia $\times$ Epidendrum $\times$ Cattleya $\times$ Sophronitis

\subsubsection{Natural Hybrids}

Laeliocattleya elegans, a cross between Laelia purpurata and Cattleya guttata. The flowers are greenish white. Miniature types like Laelia braderi, Laelia longipes and Laelia liliputiana having butter yellow, and white and lavander flowers, respectively, are used as pot plants.

\subsubsection{Common Commercial Hybrids}

\subsection{Laelia}

'Tropical Mojo', 'Milpest', 'Rock Ruby', ‘Akiras Spring’, 'Bonnie Bonita', 'ViDoran', 'Newberry Glow’, ‘Rocket Sprite', ‘Stirling Dickinson', 'Fran’s Fuchsia’, ‘Flash’, ‘Gold Snood', 'William Curtis', ‘ Aphrodite', 'Venus’.

\subsection{Laelio-cattleya}

'Hidden Agenda', 'Magic Road', 'Samba Crown', ‘Tropical Fashion', 'Higher Ground', 'Mini Case', 'Nobiles General', 'Spring Parade’, 'Upstrart', 'Harmony Show', 'Julie Anne’, 'Beautiful Park', 'Orange Sunset','Carbon Lines', 'Good Friend', 'Pat's Golden Dream', 'Sunlight Kiss', ‘Sweet Cream', 'Penny Love', ‘Big Lucy’, ‘Blue Boy’, ‘Gatton Park'.

\subsubsection{Medicinal Laelia}

Laelia autumnalis has antihypertensive and vasorelaxant activities. In Mexico, it is used for the treatment of diarrhea and abortion. 


\subsubsection{Cultivation}

They are intermediate orchids requiring cool periods in winter and enjoy moderate shade and humidity during vegetative growth. Temperature requirements vary from 12 to $18^{\circ} \mathrm{C}$ depending upon species. They are best grown in earthen pots or in hanging baskets. The plants prefer bright sunlight with an intensity of 1800-2400 foot candles and a humidity of 50 to $65 \%$. Plenty of water is required when the roots are in the active phase of growth. Watering is to be reduced during resting in winter. They grow well in tree fern fibre. Fertilizing with dilute, well rotten oil cake (1 kg in 10 gallons of water) at fortnightly intervals is beneficial.

\subsubsection{Miltonia}

Miltonia consists of 20 species of sympodial epiphytic orchids from Brazil. They are also called 'Pansy Orchids' at higher elevations. These orchids are characterized by sessile, flattened pseudobulbs and thin leaves arising from pseudobulbs. Inflorescence is single flowered or multiflorus raceme. The flowers are large, $10 \mathrm{~cm}$ across and yellow, reddish purple, white, pink or brown in colour.

\subsubsection{Genetic Resources}

Miltonia clowesii: Native to Brazil. The pseudobulbs are elongated, ovoid-oblong with linear-ligulate glossy leaves. Inflorescence is 7 to 10 flowered, dense, erect or arching and $60 \mathrm{~cm}$ tall. Flowers are yellow with whitish violet lip and produced in September to November.

Miltonia Roezlii: This species is native to Columbia and Panama. The pseudobulbs are ovoid-oblong with solitary narrow thin leaves. The inflorescence is 2 to 5 flowered, slender. The flowers are scented, whitish purple in colour and produced in October or spring.

Miltonia spectabilis: A robust rhizomatous orchid with flat pseudobulbs and paired linear ligulate leaves. Inflorescence is erect and $20 \mathrm{~cm}$ tall. The flowers are long lasting, heavily textured and whitish violet.

Miltonia vexillaria: Native to Coulmbia and Brazil. The pseudobulbs are clustered, tipped by 2 leaves and arranged basally with 4 to 6 leaves. Inflorescence is 4 to 12 flowered and $50 \mathrm{~cm}$ long. The flowers are fragrant, $8.5 \mathrm{~cm}$ long, rose- red or lilac- rose in colour and are produced in April-June.

\subsubsection{Bigeneric Hybrids}

Milpasia $=$ Miltonia $\times$ Aspasia

Miltasia $=$ Miltonia $\times$ Brassia

Odontonia = Miltonia $\times$ Odontoglossum

Miltodonium = Miltonia $\times$ Oncidium 


\subsubsection{Trigeneric Hybrids}

Aliceara $=$ Miltonia $\mathrm{x}$ Brassia $\mathrm{x}$ Oncidium

Colomanara $=$ Miltonia $\mathrm{x}$ Odontoglossum $\mathrm{x}$ Oncidium

\subsubsection{Tetrageneric Hybrids}

Withnerara $=$ Miltonia $\mathrm{x}$ Aspasia $\mathrm{x}$ Odontoglossum $\mathrm{x}$ Oncidium

\subsubsection{Intervarietal Hybrids}

'Puna Gold', 'Shaini’s Star', 'Enzan Sunday', 'Mauri Star', 'Enzan Floss', 'Red Rock', 'Tear Drops', 'Yellow Sands', ' Black Waters', 'George W, Bush', 'Indian Hollow', 'Cast Sand', 'Emily’s Delight', 'Ananda Apple', 'Whale Bay’, 'Daydream', 'Solar Storm', 'Angel Eyes', ‘Top Prize Capitula Redwood', 'Bingo', 'Kismet Sena', 'Saffron Butterfly', 'Dream River', 'Moon River', ‘Coconut Cream', 'Spring Jewel’, ‘Blackout', 'Dear Lady'.

\subsubsection{Interspecific Hybrids}

'Marion Primmer', 'Wine Leopard FCA', 'Menina Taylor', ‘Tropic Skies', 'Joyce Hill', 'Edwin Oka', ‘Stellina'.

\subsubsection{Variety-species Hybrids}

'Invisible Man', 'Miami Spectacular', 'Walnut Valley Glade’, 'Danny Denton', 'Princess Diana', 'Pink Sand', ‘ Enzan Lady’, 'Spectacular Dawn', ‘Candid Ruby’, 'Komoda Marvel', 'Harry', 'David Manzur', 'Rick Hood', 'Pacific Wars'.

\subsubsection{Natural Hybrids}

Miltonia x bluntii, Miltonia x cogniauxiae, Miltonia x flava, Miltonia x leucoglossa, Miltonia x rosina, Miltonia x cuneata, Miltonia x binottii, Miltonia x lamarckiana, Miltonia $x$ petersiana

\subsubsection{Cultivation}

The high elevation orchids require a specialized structure and must be grown in cool house. Bright diffused light is necessary for miltonias to bloom. Usually, a temperature range of $10-15^{\circ} \mathrm{C}$, relative humidity of $50-70 \%$ and light intensity of $2400-3600$ foot candles is ideal for these plants.

A perfectly drained compost consisting of chopped osmunda and chopped sphagnum moss is good. The plants are well grown in small pots. The tropical species require 
well lighted locations with warm temperature. It is also best to plant them in well drained, lightly packed compost mixture of equal parts of chopped tree fern fibre and dust tree bark preparation. They require abundant water and high humidity. Watering once a week during winter and twice a week during summer is sufficient. A complete fertilizer of NPK (30: 10: 10) in liquid form should be sprayed at monthly intervals.

\subsubsection{Odontoglossum}

Odontoglossum consists of 300 species of epiphytic and lithophytic orchids from Mexico to Bolivia and Brazil. The pseudobulbs are tipped by 1 or 2 leaves. Inflorescence arises from the base of the pseudobulbs, is erect or arching, and bears one too many large and beautiful flowers. The flower colour is variable from pure white spotted and blotched with other hues of yellow to chestnut brown.

\subsubsection{Genetic Resources}

Odontoglossum citrosmum: Native to Mexico. The pseudobulbs are round bearing two leathery leaves at the tip. The inflorescence is 10 to 15 flowered and drooping. The flowers are scented, white splashed with pink, with a pink lip and are produced in May. Odontoglossum cordatum: Native to Mexico, Guatemala, Hondurus and Costa Rica. The pseudobulbs are clustered, ovoid-ellipsoid to ellipsoid with solitary, elliptic-lanceolate or oblong ligulate leaves. Inflorescence is erect with few too many flowered. The flowers are $7.5 \mathrm{~cm}$ in diameter, yellow in colour and produced in April-May.

Odontoglossum crispum: A beautiful species from Columbia. The pseudobulbs are egg shaped with compressed and furrowed edges. The leaves are 2 to 3, soft textured, narrow and linear ligulate. The inflorescene is erect or arching, and dense with many flowers. The flowers are white and tinted with pink, having pinkish white lip and produced during February to April.

Odontoglossum grande: This species is native to Mexico and Guatemala. The pseudobulbs are large, roundish and clustered and furrowed with 1 to 3 thick heavy textured leaves. The inflorescence is erect, stout, 6 to 8 flowered. The flowers are large, $15 \mathrm{~cm}$ across, waxy and long lasting, yellow streaked with brown or red purple and white lip. The flowers are produced during December to March.

Odontoglossum Krameri: The species is native to Mexico and Costa Rica. The pseudobulbs are small, compressed, clustered, roundish and tipped by single, leathery, elliptic lanceolate leaves. The inflorescence is short, erect and 3 to 5 flowered. The flowers are $4 \mathrm{~cm}$ across, lilac pink segment edged with white and produced during June to August.

Odontoglossum luteo-purpureum: A species native to Columbia. The pseudobulbs are robust, compressed, oval and tipped with two large ensiform leaves. The inflores- 
cence is erect and 8 to 12 flowered. The flowers are $10 \mathrm{~cm}$ across, red chestnut brown in colour with white lip and produced during April-May.

Odontoglossum pulchellum: Native to Mexico and Guatemala. The pseudobulbs are clustered, compressed, and ellipsoid-oblong to ovoid with 2 to 3 very narrow leaves. The inflorescence is erect and 6 to10 flowered. The flowers are long lived, very scented, white and produced during March to April.

Odontoglossum rubescens: This species is native to Guatemala, Nicaragua and Mexico. The pseudobulbs are ovoid, clustered, compressed with solitary, ovate-lanceolate or oblong -elliptic leaves. The inflorescence is 2 to 4 flowered and bracted. The flowers are $7.5 \mathrm{~cm}$ across, narrow, white streaked with brown, have an undulated white lip, and are produced during January to March.

Odontoglossum stellatum: This species is found in Guatemala and Mexico. The pseudobulbs are clustered and tipped solitary leaves. The inflorescence is short, slender and 1 to 2 flowered. The flowers are $5 \mathrm{~cm}$ across, tangy brown with white or pink lip and are produced in the spring season.

Odontoglossum tripudians: This species is widely distributed in Columbia, Eucador and Peru. The inflorescence is many flowered and $7.5 \mathrm{~cm}$ long. The flowers are yellow and produced during the spring season.

Odontoglossum triumphans: This species is native to Colombia. The pseudobulbs are compressed with leathery dark green leaves. Inflorescence is many flowered and erect. The flowers are $12.5 \mathrm{~cm}$ across and golden yellow with reddish brown spots.

Odontoglossum wallisii: This species is native to Colombia and Venezuela. The pseudobulbs are compressed and round with arching leaves. Inflorescence is drooping and loosely 10 to 15 flowered. The flowers are pale yellow with reddish brown stripe, $6.5 \mathrm{~cm}$ across and whitish purple lip and produced during winter season.

Odontoglossum cirrhosum: A magnificent species from Eucador. Flowers are pure white with heavy cinnamon spots.

Odontoglossum harryanum: This species is native to South America. The inflorescence is erect, $50-90 \mathrm{~cm}$ tall and 12 flowered. Flowers are $7 \mathrm{~cm}$ across, reddish brown and segmented marked with yellow with a reddish brown and white lip.

\subsubsection{Bigeneric Hybrids}

Aspoglossum $=$ Odontoglossum $\times$ Aspasia

Odontonia $=$ Odontoglossum $\times$ Miltonia

Odontocidium $=$ Odontoglossum $x$ Oncidium

Odontobrassia = Odontoglossum $\times$ Brassia

\subsubsection{Trigeneric Hybrids}

Wilsonara $=$ Odontoglossum $\times$ Cochlioda $\times$ Oncidium

Colmanara $=$ Odontoglossum $\times$ Miltonia $\times$ Oncidium 


\subsubsection{Tetrageneric Hybrids \\ Withnerara $=$ Odontoglossum $\times$ Aspasia $\times$ Miltonia $\times$ Oncidium \\ Watsonara $=$ Odontoglossum $\times$ Brassia $\times$ Oncidiun $\times$ Tricocentrum \\ Bakerara $=$ Odontoglossum $\times$ Miltonia $\times$ Brassia $\times$ Oncidium}

\subsubsection{Inter-specific Hybrids}

'Cynthia Hill', 'Luis Salabazar', 'Mc Beans Elizabeth', 'Spotted Croc', 'Mayapan', 'Quito', ‘Colocris', ‘Mums Tiger', ‘Ann', ‘High Street', 'Uro-Day’, Cormac', ‘Gay Enchanment', 'Gay Starshooter'.

\subsubsection{Inter-varietal Hybrids}

'Italian Job', 'Joyce Stewart', 'Pepe Gerald', 'Purple Rain', 'Katherine Jenkins', 'Roy Wittwer', 'Laguna Blanca’, 'Precocious', ‘Snow Fall’, 'Pesky’, ‘Queen of Mars’, 'Stam Point', 'Holiday Yellow’, 'Ronald Norman', 'Bridget Ring Lawless', ‘John Hanry Hanson', 'Point Pesky'.

\subsubsection{Variety -Species Hybrid}

'Doctor Tom', 'Bob Hamilton', Winter Star', 'Age of Reality','Rocky Road', 'Black Diamond', 'San Damino Royal', 'La Platte', ‘Oratia Bride', 'Golden Crisp', 'Offalman', 'Enzan Yankee’, ‘Ken Armour’, ‘Geneva Snow’.

\subsubsection{Cultivation}

The plants prefer a bright light with the intensity of 2000-2500 foot candles, a day temperature $25^{\circ} \mathrm{C}$ and night temperature of $15^{\circ} \mathrm{C}$ and $40-80 \%$ humidity with free movement of air. Bark mixes to be the standard potting media for odontoglossums. One mix consists of one part coarse sand, one part coarse shredded peat, one part perlite and four parts fine bark. In an 8-inch pot for these ingredients, a small handful each of bone meal and dolomitic lime can be added. Applications of NPK (30: 10: 10) twice a month is ideal for successful growth of plants.

\subsubsection{Renanthera}

Renanthera consists of 12 species of epiphytic or lithophytic orchids from China, Himalayas, the Philippines, Indonesia and New Guinea. Plants are monopodial, vinelike, pseudobulbless with ascending stems of intermediate growth. The leaves are leathery, distichous, thick and coriacious. A large number of aerial roots is produced from the stem of plants. The inflorescence arises from the axils of leaves (upper) 
and produce few to many flowers. The flowers are $9 \mathrm{~cm}$ across, scarlet, red orange, crimson to yellow in colour.

\subsubsection{Genetic Resources}

Renanthera coccinea: This species is native to Burma, South China and Thailand. The stems are ascending, erect and freely rooting with leathery, well spaced, yellowish green leaves. The inflorescence is produced from the stem opposite one of the upper leaves, $1.2 \mathrm{~m}$ tall with about 150 flowers. The flowers are large, $8.5 \mathrm{~cm}$ across, long lasting with red petals and vermillion sepals and yellow crimson lips and are produced during June -July.

Renanthera imschootiana: An endangered species, restricted to Manipur and other neighbouring states of North East India, which is commonly called 'Red Vanda'. The stems are solitary, $90 \mathrm{~cm}$ long arranged with a set of leaves closely packed on the stem. Inflorescence is horizontal, branched bearing more than 20 bright crimson flowers with red spots on a pale orange back ground of its dorsal sepal and petals. The flowers are long lasting, $6 \mathrm{~cm}$ across and are produced during April-May.

\subsubsection{Bigeneric Hybrids}

Renades $=$ Renanthera $x$ Aerides

Aranthera $=$ Renanthera $\times$ Arachnis

Renancentrum $=$ Renanthera $\times$ Ascocentrum

Renanthopsis $=$ Renanthera $x$ Phalaenopsis

Renantand $a=$ Renanthera $x$ Vanda

Renanopsis $=$ Renanthera $x$ Vandopsis

\subsubsection{Trigeneric Hybrids}

Sappanara $=$ Renanthera $x$ Arachnis $x$ Phalaenopsis

Holttumara $=$ Renanthera $\times$ Arachnis $x$ Vanda

Moirara $=$ Renanthera $x$ Phalaenopsis $x$ Vanda

\subsubsection{Renanthera Hybrids}

'SCGB Kylin', 'Datin Blanche’, 'Olbery’, 'Hooi Sew Yong’, 'John Losgar’, 'Red Leopard', 'Scarlet Belle', 'Chanachae', 'Serdang', 'Brady Crocker', '20 th WOC Singapore-2011', 'Bart Motes'.

\subsubsection{Renanstylis Hybrids}

'Bangkok Beauty', 'Teo Choo Hong', 'Carl Niemann' 


\subsubsection{Renantanda Hybrids}

'Forever Yvonne', 'Inspiration Ng Teng Fong', 'Ladda Glow'; 'Polyetheramine Singapore', 'Momon Shija', 'Paul Gripp', 'Science Arts', 'Memoria Charles Darwin', 'Prof. G.J. Sharma', 'Kebisana Shija', 'Mary Motes’, ‘Kofi Annan'.

\subsubsection{Renanthopsis}

'Bob Banister', 'John Mason SCBG Canary', 'Lieke Jjoa', 'Persian Carpet', 'Dancing Stars'

\subsubsection{Renanapsis}

'Santa Cruz'

\subsubsection{Uses}

Renanthera orchids are ideal for pot plants, hanging baskets and for mounting on trees.

\subsubsection{Cultivation}

The plants require a warm, moist atmosphere and airy and well lighted locations during the growing seasons. Full sun exposure is usually needed for proper flower production. The plants must be fastened on a block of fern stem or wood, to which they become firmly attached by their roots. These plants must be planted in a compost media consisting of tree fern fibre, mixture of fir bark and charcoal. The temperature of $15-30^{\circ} \mathrm{C}$, light intensity of 4000 to 5000 foot candles and humidity of 60 to $70 \%$ are found to be optimum for their growth and flowering. The plants are to be watered daily during summer months and twice a week during winter months. A complete fertilizer of NPK (20:20:20) in liquid form should be sprayed at weekly intervals in summer and fortnightly intervals in winter.

\subsubsection{Rhyncostylis}

Rhyncostylis consists of 4 species of monopodial epiphytic orchids distributed in India, Burma, Thailand, Malayasia, Indonesia, Sri Lanka, the East Indies and the Philippines. These orchids are commonly known as 'Foxtail Orchids' and are considered the state flowers of Assam and Arunachal Pradesh. These are stout, short stemmed plants with thick and leathery linear-oblong leaves closely arranged on the stem. The inflorescence is erect or drooping, and densely covered with small, colourful showy flowers. The flowers are red, magenta, blue spotting, reddish lavender and white in colour. 


\subsubsection{Genetic Resources}

Rhyncostylis gigantea: This species is native to Thailand and Burma. The stems are stout with tongue shaped, heavy, leathery leaves. The inflorescence is pendulous, $45 \mathrm{~cm}$ covered with many small flowers. The flowers are sweet scented, long lasting, waxy, $2.5 \mathrm{~cm}$ across with pure white sepals and petals spotted red-violet and magenta and produced during autumn and early winter.

Rhyncostylis retusa: This species is native to India, Sri Lanka and the Philippines. The stems are robust and woody with small stout aerial white roots. The leaves are leathery, strap shaped, linear, deeply channeled and arching. The inflorescence is pendulous, $60 \mathrm{~cm}$ long, many flowered and cylindrical. The flowers are waxy, short or long lived, sweet scented, $1 \mathrm{~cm}$ across with white sepals and petals spotted with bluish purple and are produced during April-May.

Rhyncostylis coelestis: Native to southeast Asia. The plants are dwarf with stiff folded leaves that curve downwards. The flowers are 2-tone blue, scented and long lasting. Rhyncostylis violacea: This species bears many miniature lavender and white flowers, which are produced during winter and spring season.

\subsubsection{Common Uses}

In Assam, the flower spike of Rhyncostylis retusa known as 'Kopou Phul', is used by girls to adorn their hair during the summer festival. Hybrids are used as cut flowers or in bouquet making and flower arrangements.

\subsubsection{Bigeneric Hybrids}

Rhynchorides $=$ Rhyncostylis $x$ Aerides

Aranchostylis $=$ Rhyncostylis $x$ Arachnis

Neostylis = Rhyncostylis $x$ Neofinetia

Rhynchonopsis $=$ Rhyncostylis $x$ Phalaenopsis

Renanstylis = Rhyncostylis $x$ Renanthera

Rhyncovanda $=$ Rhyncostylis $x$ Vanda

\subsubsection{Trigeneric Hybrids}

Vascostylis = Rhyncostylis $x$ Ascocentrum $x$ Vanda

Rhyncostylis = Rhyncostylis $x$ Doritis $x$ Phalaenopsis

Yapara $=$ Rhyncostylis $x$ Phalaenopsis $x$ Vanda

\subsubsection{Rhynchorides Hybrids}

'Thai Gem', 'Norma', 'Alice;s Wally', 'Bangkok Sunset' 


\subsubsection{Rhynchostylis Hybrids}

'Charles Marden Fitch'

\subsubsection{Rhyncholaeliocattleya Hybrids}

'Gabgab Castro', 'Malvarosa Pearl', 'Robinson’s Delight', 'Chief Journey’, 'Aguti Gold', 'Little Circle', 'Butterfly Wings', 'Magic Morning', 'Chief Birde', 'Chief Pink', 'Crimson Circle', 'Bold As Love', 'Julian’s Shaw', 'Jims Beauty', 'Omi Melody’, 'Proda Flora', 'Scarlet Bay', 'Salmon Sensation', 'Himalayan Aspiration', 'Innocent Mastiff', 'Lhonak Sunset', 'Pradhan's Delight', 'Rumtek Jewel', 'Scented Serendipity’, 'Sikkim Sentinal', 'Sikkim Majestic', 'Sikkim Accolade', 'Sukhim Song', 'Big Shot','Deception Girl', 'Fire Rose’, 'Fire Lake’, ‘Agatha Fire’, ‘Agatha Lim', ‘Volcano Glory’, ‘Wild Promise’, 'June Simpson', 'Tinker Bell'.

\subsubsection{Rhynchosophrocattleya Hybrids}

'Chief Blue', 'Chief Heart', 'Comet Pink', 'Long Run', 'Golf Pink', 'Gorgeous Lady', 'Alpha Plus Peacock', 'Exotic Ruby’, 'Red Bay’, ‘Alphs plus Pink', 'Skip Wilson', ‘Tropical Punch', 'Giant Beauty', Fruit Island', 'Lovely Air’, 'Sakura Grand', 'Ashahi Delight'

\subsubsection{Rhynchovola Hybrid}

'Green Pixie'

\subsubsection{Rhyncattleanthe Hybrids}

'Buddy Bay', 'Burana Fire', 'Samba Script', 'Typical Worth', 'Shigfong White', 'Charm', Alpha Plus Buddha', 'Purple Rainbow', 'Golden Bell', 'Peter Lin', 'Nobile’s Teens', 'Nobile’s Coralina', 'Nobile’s Toffee', 'Algestor Gold', 'Sikkim Treasure’, 'Tendong Glow', 'Life’s Charm', 'Laughing Magic', 'Silent Moon', 'Atomic Jungle', 'Hot Blooded', 'Sea of Love', 'Uptown Girl’, ‘Alpha Plus Candy', 'Brown Tone', 'Clinton Lewis', 'Little Treat', 'California Love', ‘Chocolate Rose’, 'Heart Warmer', ‘Sweet Sound'.

\subsubsection{Rhynchovanda Hybrids}

'Wilton Hill', 'Jammie Harper', 'Apichart', 'Noo Noi', 'Peter Draper', ' Brighton's Albino', 'Prairie Lady’.

\subsubsection{Rhyncattleya Hybrids}

'Olor de Otoño', 'Cinco de Mayo', 'Rios De Oro', 'Tadong Delight', 'Hsinying Moves', 'Irvine Sunset', 'Deception Sweetheart', 'RIO’s Treasure', 'Petit Prisme’, 'RIO’s Spectacle', 'Chuchemen'. 


\subsubsection{Rhyncobrassoleya Hybrids}

'Chief Cindy', 'Starry’, 'Taurus', 'Tetraspotts', 'Bosque Antiguo', 'Ramar’s Happiness', 'Roberts Dodson', 'Sedona's Surprise', 'Tranquility', ‘Golden Angel Lemon Tang’, 'Pink Blush'.

\subsubsection{Medicinal Rhyncostylis}

Roots of Rhyncostylis retusa are effective against rheumatisms. Plants are also used against asthma, tuberculosis, cramps, epilepsy, vertigo, palpitation, kidney stones and menstrual disorders.

\subsubsection{Cultivation}

These plants require high humidity, moderate shade and plenty of water during active phase of growth. They require bright light with an intensity of 3000-4000 foot candles and strong air movements all the times. These orchids are ideal for hanging baskets. They grow well in large chunks of tree fern fibre or in a medium of chunks of hardwood charcoal.

A day temperature of $30-32^{\circ} \mathrm{C}$ and night temperature of $24-25^{\circ} \mathrm{C}$ and relative humidity of $80 \%$ in summer and $60-70 \%$ in spring and winter are ideal for their active vegetative growth and flowering. Plants should be watered heavily while actively growing, but aeration around the roots must be excellent, allowing the roots to dry rapidly after watering. For plants grown in pots or baskets, the medium must never become water logged or soggy. These plants are heavy feeders and respond very well with the dilute solution of $0.3 \%$ NPK (20: 20: 20) sprayed twice a month.

\subsubsection{Zygopetalum}

Zygopetalum consists of 25 species of terrestrial, lithophytic or epiphytic orchids from Brazil, Bolivia, Peru, Paraguay, Venezuela and New Guinea. The pseudobulbs are ovoid with a distinct sheath, $5 \mathrm{~cm}$ to $7.5 \mathrm{~cm}$ tall and strong with lanceolate, disticous leaves. The inflorescence develops from the base of pseudobulbs, and is arching or erect in nature. The flowers are fragrant and long lasting in shades of brilliant green, blue or purple. The flowers are $5 \mathrm{~cm}$ to $7.5 \mathrm{~cm}$ across with wavy margins. They are excellent for cut flowers and corsages.

\subsubsection{Genetic Resources}

Zygopetalum cerinum: This species is native to Columbia with degenerative pseudobulbs and oblong leaves. Flowers are borne singly, creamy white with yellow lip streaked with purple. 
Zygopetalum crinitum: This species is native to Brazil with ovoid to conical pseudobulbs and fleshy. Coriaceous, lanceolate and glossy leaves. The inflorescence is $45 \mathrm{~cm}$ long and 3 to 10 flowered. The flowers are $8 \mathrm{~cm}$ across, scented with green segments, maculated brown and have a white lip streaked with violet and are produced in December-January.

Zygopetalum mackayi: A rare and beautiful species from Brazil with long, erect and curving leaves. The inflorescence is $90 \mathrm{~cm}$ tall and 5 to 10 flowered. The flowers are large, $8.5 \mathrm{~cm}$ across, scented, long lived with yellowish green petals and sepals maculated with violet purple and white lip intricately veined with red and blue, and produced during December.

Zygopetalum intermedium: A popular species, native to Brazil with ovoid conical pseudobulbs and glossy bright green leaves. The inflorescence is $60 \mathrm{~cm}$ long, 10-12 flowered and attractive. The flowers are $7.5 \mathrm{~cm}$ across, long lasting, fragrant, yellowish green with purple brown blotches and white lips with dots of blue and produced in December.

Zygopetalum wendlandii: This species is native to Costa Rica and has degenerative pseudobulbs and lanceolate leaves. The flowers are $10 \mathrm{~cm}$ across, pale green in colour and produced at the end of summer to the beginning of autumn.

\subsubsection{Intergeneric Hybrids}

Zygonisia = Zygopetalum $\times$ Aganisia

Chondropetalum $=$ Zygopetalum $x$ Chondrorhynca

Zygocolax $=$ Zygopetalum $x$ Colax

Zygocaste $=$ Zygopetalum $x$ Lycaste

\subsubsection{Common commercial Hybrids}

'Blue Blood', 'Blue Bear', 'Imagination', 'Tanzanite', 'Millie', 'Black Plague', 'Kiwi Black', 'Kiwi Choice', 'Pioneer', 'Tasman', 'New Era', 'Dark Star', 'Impulse', 'Intuition', 'Great Eisen', 'Blue River', 'Indigo Skies', 'Blue Banks', 'Bon Voyage', 'Centenary', 'Hot Springs', 'Blackjack', 'Night Hawk', 'Violet Moon', 'Leopard Prince', 'Blue Blood', 'Big Country', 'Hawker'

\subsubsection{Cultivation}

Zygopetalums thrive well in a temperature range of $20-26^{\circ} \mathrm{C}$ during day time and $10-15^{\circ} \mathrm{C}$ during night. They require bright light in the $3000-4000$ foot candles range. During summer season, it needs $40 \%$ shade cloth. They love water during their active growth period and are watered at 5-7 days intervals. A potting mixture consisting of cocopeat, cocochips and tree barks is ideal. They are easily propagated through division of pseudobulbs. 